\title{
IDEAL MODEL FOR INVESTIGATING URBAN FORM EFFECTS ON URBAN HEAT ISLAND AND OUTDOOR THERMAL COMFORT: A REVIEW
}

\author{
Elham Sanagar Darbani ${ }^{1} 凹$ (D), Danial Monsefi Parapari ${ }^{2} \square$ (iD) \\ Master of Urban design, Department of urban planning and design, Islamic Azad University, Mashhad, Iran \\ ${ }^{2}$ Assistant professor, Faculty of Architectural Engineering and Urbanism, Shahrood University of \\ Technology, Shahrood, Iran
}
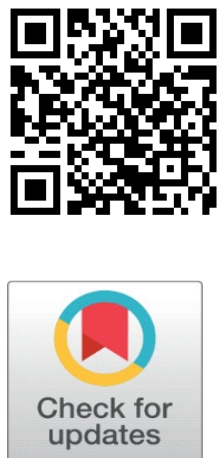

Received 1 September 2022

Accepted 15 September 2022

Published 16 February 2022

\section{CorrespondingAuthor}

Elham Sanagar Darbani,

ElhamSanagar13@Gmail.com

DOI 10.29121/IJOEST.v6.i1.2022.275

Funding: This research received no specific grant from any funding agency in the public, commercial, or not-for-profit sectors.

Copyright: (C) 2022 The Author(s). This is an open access article distributed under the terms of the Creative Commons Attribution License, which permits unrestricted use, distribution, and reproduction in any medium, provided the original author and source are credited.

OPEN $\bigcirc$ ACCESS

\section{ABSTRACT}

In recent decades, urban planners have endeavored to mitigate climate change, by adaptation programs in order to alleviate its adverse effects on human health and wellbeing. Outdoor thermal comfort as an environmental factor affects human health, as proven by various research studies conducted in different climates. The aim of this paper is to explore the components of urban heat island, outdoor thermal comfort, and urban form. The relationship between these keywords and variables that affect outdoor thermal comfort was also analyzed. The research method is descriptiveanalytical and besides that, the qualitative research method has been used. The components of each keyword have been extracted based on professional theories. Finally, the ideal model of outdoor thermal comfort is proposed. This paper gives a comprehensive view to urban heat islands, urban form, and outdoor thermal comfort.

Keywords: Urban Heat Island, Outdoor Thermal Comfort, Urban Form, Conceptual Model

\section{INTRODUCTION}

High air temperature in urban environments leads to several health problems and even increases mortality rates. Akbari and Konopacki (2004), Rosenfeld et al. (1998) Currently, there is a great body of scientific research on the sustainable built environments, which prove the impact of urban form on sustainability Jenks and Burgess (2000). To have comfortable urban environments that fit human health, cities and urban environments should be free from dissatisfaction and discomfort Yilmaz et al. (2013). Outdoor thermal comfort not only has a direct impact on human health, but also its standards are an important precursor to energy efficiency and sustainability. Considering the crucial need to diminish the economic and environmental costs of energy consumption, much research on outdoor thermal comfort has attracted researchers for decades Djongyang et al. (2010). Outdoor thermal comfort is a factor that improves human health Xu et al. (2018) significantly in low-income communities, increases the attendance of people in urban spaces and public activities Ghasemi et al. (2015), and helps to decrease the cost of energy consumption Kwon et al. (2019). The main aim of this paper is to determine the relationship between three keywords: Urban Heat Islands, Urban Form, and Outdoor Thermal Comfort. The results of the paper help the future studies to gain a better understanding of the main parameters 
which influence human health and moreover give a concept for evaluating outdoor thermal comfort in urban spaces. The innovation of the present research lies in providing a comprehensive perspective on climate change, urban form, urban heat islands, and outdoor thermal comfort for the first time.

\section{METHODOLOGY}

\subsection{LITERATURE SELECTION}

The aim of this study is to describe relationships between outdoor thermal comfort, urban heat island, and urban forms. Thus, relevant papers indexed in Web of Science and Scopus were extracted in "Publish or Perish" software and then "VOS" software package was used to demonstrate the map of the studies. The keywords for searching were as follows:

"Microclimate" and "climate comfort", "Microclimate" and "outdoor thermal comfort", "climate comfort and outdoor thermal comfort", "Outdoor thermal comfort" and "urban heat islands", "microclimate and urban heat islands", "urban form". "Outdoor thermal comfort", "urban form". "Outdoor thermal comfort", "urban heat islands"

The number of papers in terms of "Outdoor thermal comfort" and "urban form" were limited and with in-depth investigation of other sources such as books, the urban form parameters were extracted and categorized in 5 clusters. Papers published during 1900 to 2020 were selected for this study. Some articles were not related to the object of this study and were excluded. Figure 1 shows the outdoor thermal comfort research and keywords related to it until 2020.

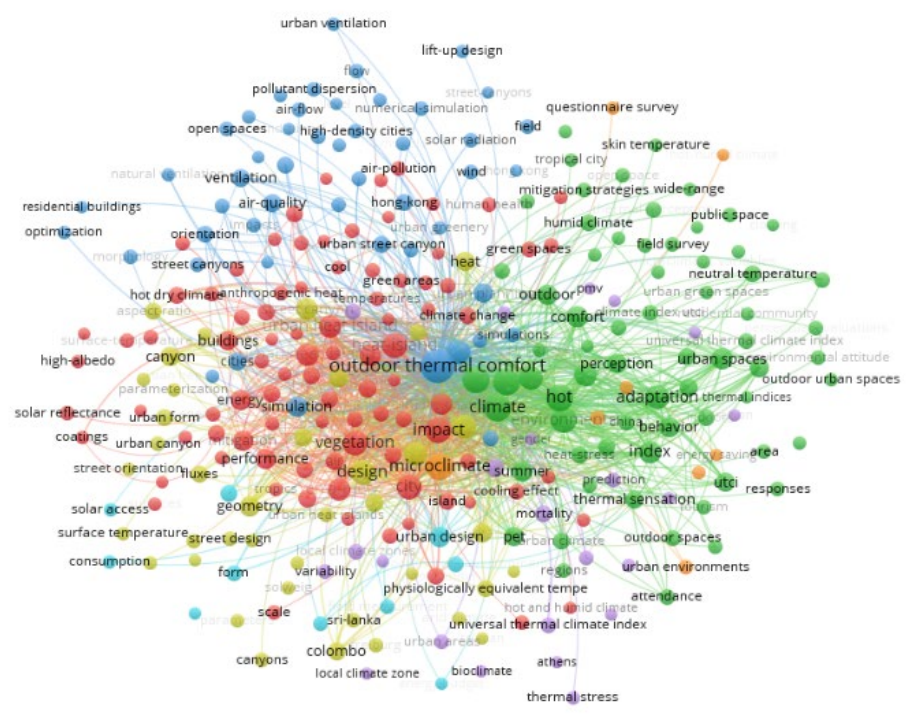

Figure 1 Term co-occurrence map

Papers with high citations and relevant titles were reviewed accurately to ensure their relevance with outdoor thermal comfort, urban heat island, and urban form. For the first step, the main keywords in terms of outdoor thermal comfort were extracted based on the aim of the paper. The second step was to find the relations between keywords. At the final stage, urban form parameters that have an impact on UHI were reviewed. 


\subsubsection{CLIMATE CHANGE}

Since the 1950s global measurements show that $\mathrm{CO}_{2}$ emissions has increased by $18 \%$ annually. The first program to discuss climate change was presented in 1972 at the National Climate Change Summit Roaf et al. (2009). Climate change is an undeniable phenomenon as cities increasingly emit greenhouse gases and see the consequences of climate change as rising temperatures in the atmosphere Prasad et al. (2009) Urban environments are strongly influenced by various climatic regions. Changes in urban areas and building materials (i.e. concrete, asphalt, etc. that absorb more solar energy) have an impact on the thermal environment in all climatic scalesAmirtham (2010), Oke (2006) introduced two scales for measuring meteorological data in climatic layers; vertically and horizontally. Oke (2006)

\section{Vertical Climate Layers}

In urban areas, the lowest part of the Earth's atmosphere that is affected by urban change is called the urban boundary-layer (UBL). Above UBL is mix layer and the height of it varies according to atmospheric stability and its amount as well as the effects of urban elements Erell et al. (2011). Inside the UBL layer is the surface layer, with a thickness of four to five times greater than the height of an average building, a layer that includes three-dimensional geometry and other building properties and urban open spaces materials. The surface layer is formed when air passes through a part of the ground with various building structures and absorbs the heat generated by the city. In general, this layer is influenced by the urban context. Above the surface layer is the Urban Canopy Layer, which is affected by urban forms and the thermal conditions of its surrounding surfaces. The height of the UCL is approximately equal to the average height of the buildings above ground level Amirtham (2010). According to Erell et al. (2011), it is not possible to set a specific limit and unit for this scale and it may vary depending on the geographical and human situation. The important point for this scale is that it is influenced by terrestrial factors and human actions and the urban climate is included in this scale Erell et al. (2011).

\section{Horizontal Climate Layers}

The horizontal layer consists of three scales: Meso, local and microclimate layer. The Meso scale is affected by the city and the surrounding areas, and remote sensing devices or balloons are used to evaluate it. Meso-scale studies are suitable in studies of UHI reduction due to heatwaves, storm, and urban planning layers Dai (2014). The bottom layer of the Meso-scale is the local climate, which examines urban neighborhoods and developed settlements (surface coverage, size and distance from buildings, activities, etc.). By defining the local scale, the spatial dimensions continue for several kilometers, and if we go from the neighborhood level to the whole city, we are faced with spatial dimensions that usually cover tens of kilometers Dai (2014). According to Oke (1987) the range of this scale is $100 \mathrm{~m}$ to $50 \mathrm{~km}$ Oke (1987). This scale plays an important role in the neighborhood climate scale and sustainable urban design and in fact plays an important role in connecting the micro and meso climate layersDai (2014) What is examined in this study is the microclimate, which has the most climate studies focusing on urban residents Galal et al. (2020), Muniz-Gäal et al. (2020). This layer is a reflection of urban forms effects on outdoor thermal comfort. Measurement of air temperature for outdoor thermal comfort is usually done on this scale by meteorological stations or on-site measurements. Classification of climatic scales and its application in urban studies is shown in Figure 2. 


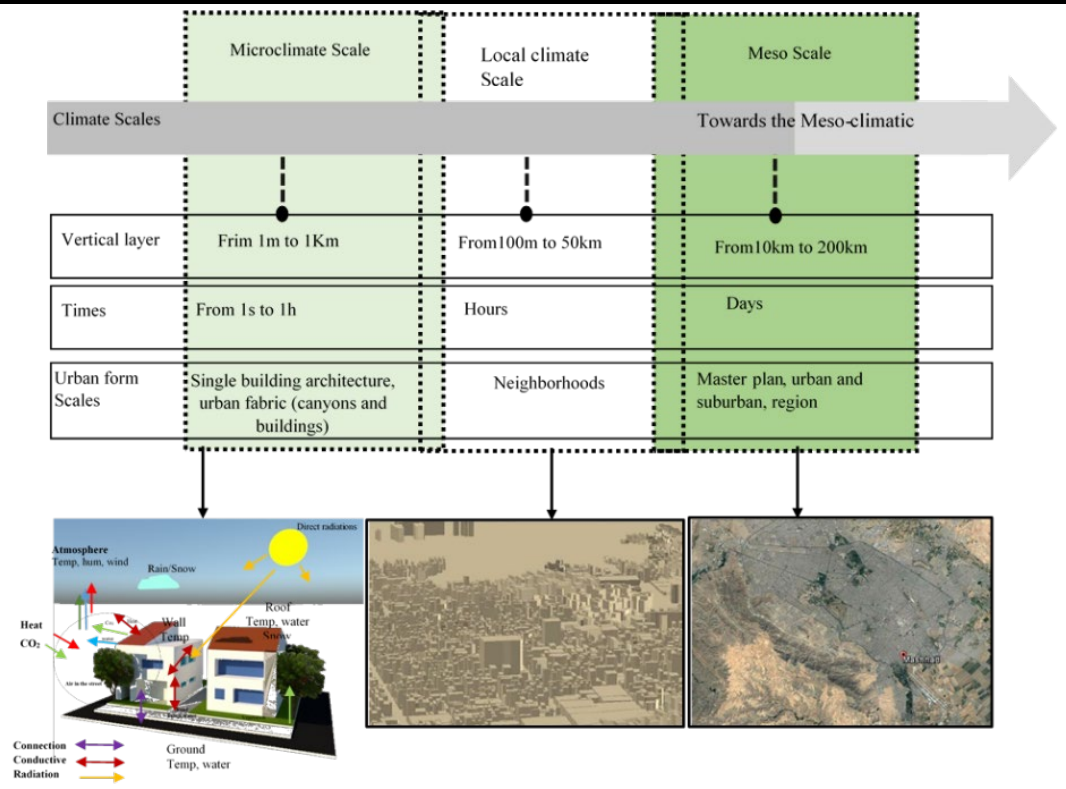

Figure 2 Classification of climatic scales and its application in urban studies

\subsubsection{URBAN HEAT ISLAND (UHI)}

Urban Heat Islands increase urban energy consumption, reduce outdoor thermal comfort, and significantly intensify risks to human health Wang and Akbari (2016). The concept of UHI was first introduced by Howard in London in 1833 Oke (1982) and since the 1990s various studies have been conducted in different climate zones Yow (2007). Studies show that urban areas are generally warmer than rural areas, especially during nights, which is referred to as the UHI effect Lilly and Devadas (2009). UHI in summer causes outdoor thermal discomfort Anand et al. (2015), increases mortality and diseases, Huang et al. (2019), energy demand and costs Mohajerani et al. (2017), Akbari (2005), greenhouse gas emissions Chen and You (2020), and decreases water quality (Nuruzzaman 2015 Roa-Espinosa et al. (2003) and air quality. However, this phenomenon has positive effects in winters as it reduces the use of heating devices and energy consumption. Causes of the UHI formation are classified into two main types, (a) Natural factors: meteorology (cloud cover, wind speed, and humidity) Shahmohamadi et al. (2011),(b) man-made factors: urban forms, low albedo of materials Morini et al. (2016), high anthropogenic heat Raj et al. (2020), increasing the use of air conditioners Lundgren-Kownacki et al. (2018), reducing green coverage and vegetation Aboelata and Sodoudi (2020), Akbari et al. (2001), urban canopy Masson (2006), blocking the wind path Priyadarsini et al. (2008), and land-use Pramanik and Punia (2019). Factors that cause the difference in air temperatures between urban and rural areas can be summed up as follows:

- Heat capacity, thermal conductivity, reflectivity, and emissivity properties of construction materials that absorb more solar energy in urban areas.

- Anthropogenic heat emissions by buildings, air conditioning, transportation, and industries

- High-density buildings in urban areas block the view of the sky and affect the release of heat as long-wave radiation at night; and also reduce wind speeds and inhibits cooling by convection $\mathrm{Ng}$ (2010). 


\section{Urban Heat Island Types}

UHI occurs on the surface and at different altitudes Oke (2004). There are two types of Heat Islands, (a), urban surface heat islands (USHI) and, (b) atmospheric heat islands (AHI). The second heat islands include the Boundary Layer Heat Island (BLHI) and the Canopy Layer Heat Island (CLHI) Yow (2007). The temperature variation between the urban areas and suburban areas is known as the SUHI. The surface urban heat island (SUHI) is a nocturnal UHI, which occurs after sunset and it shows the variation of urban forms such as buildings roofs, walls, pavements materials, trees, and vegetation. The surface urban heat islands intensity is defined as:

$$
\text { SUHII=T } T_{\text {urban }}-T_{\text {suburban }}
$$

Where $\mathrm{T}_{\text {urban }}$ depicts the mean temperature of the urban area, and $\mathrm{T}$ suburbs represents the mean temperature of the suburban area.

AHI varies according to the intensity, temporary behavior of the spatial shape, and the degree of homogeneity. The importance of the urban boundary layer is more for humans to study the effects of wind flow and the distribution of air pollution over cities Oke (2004). Heat Islands above the city are measured using balloons or from tall towers Roth and Chow (2012). It is also possible to explore these islands with remote sensing technology. These Heat Islands can be measured directly insitu. Urban canopy layer heat islands are defined as the atmosphere located between the average building height and ground level. The CUHI intensity is defined as:

$$
\mathrm{CUHI}=\mathrm{CT} \text { urban }-\mathrm{CT}_{\text {suburban }}
$$

Where $\mathrm{CT}_{\text {urban }}$ depicts the mean temperature of the Canopy Layer at the urban area, and CT suburbs represent the mean temperature of the said layer at suburban

\begin{tabular}{|c|c|c|}
\hline \multirow[t]{2}{*}{ Features } & Atmospheric heat islands & Surface Heat Islands \\
\hline & $\begin{array}{cc}\begin{array}{c}\text { canopy-layer heat } \\
\text { island }\end{array} & \begin{array}{c}\text { boundary-layer } \\
\text { heat island }\end{array}\end{array}$ & \\
\hline Time of variation & $\begin{array}{l}\text { Small or absent during the day } \\
\text { Mostly during the night or before sunrise } \\
\text { in winter }\end{array}$ & , \\
\hline Intensification & $\begin{array}{c}\text { The less variety } \\
\text { during Day: } 1^{\circ} \mathrm{C} \text { to } 3^{\circ} \mathrm{C} \\
\text { During Night: } 7^{\circ} \mathrm{C} \text { to } 12^{\circ} \mathrm{C}\end{array}$ & $\begin{array}{l}\text { More temporal and spatial } \\
\text { variation } \\
\text { during Day: } 10^{\circ} \mathrm{C} \text { to } 15^{\circ} \mathrm{C} \text {. } \\
\text { During Night: } 5^{\circ} \mathrm{C} \text { to } 10^{\circ} \mathrm{C}\end{array}$ \\
\hline $\begin{array}{l}\text { evaluation } \\
\text { methods }\end{array}$ & $\begin{array}{l}\text { Indirectly: Ability to measure on site: with } \\
\text { two methods: mobile car, fixed station }\end{array}$ & $\begin{array}{l}\text { Directly using remote sensing: } \\
\text { Satellites such as Landsat, TM / } \\
\text { ETM +, MODIS, TIMS }\end{array}$ \\
\hline Display method & $\begin{array}{l}\text { Synchronous maps } \\
\text { Temperature graphs }\end{array}$ & Heat maps \\
\hline
\end{tabular}
area. Zhong et al. (2019). Table 1. shows the characteristics of USHI and UAHI.

(EPA (2014), Saud (2014), Voogt and Oke (2003)

\section{UHI mitigation strategies}


There are two types of UHI mitigation strategies scales, (a) Microclimate scale: considering buildings, canyons, and trees (vegetation), and (b) Meso-climate scale that is used for cooling cities and neighbourhoods (Figure 3).

\section{Using high albedo materials in roofs and sidewalks}

Dark roofs absorb the heat of sunlight, but roofs with bright colors significantly reflect solar energy back to the environment Akbari et al. (2001). Roofing materials with low albedo and reflection absorb the heat of radiation and increase both the temperatures of the surface material and inside environment of the building, therefore increasing the energy consumption for air conditioning Battisti et al. (2018). Considering the role of roofing materials in UHI, another problem can be observed with reduced reflectivity of the roof due to soot and dust covering the roof surface Berdahl et al. (2002), which can be easy to alleviate by cleaning and proper maintenance. Moreover, choosing the right combination of materials in paving can reduce the effects of UHI. Pavement cooling strategies were classified into the following four categories based on their operating mechanism:1) Modification of the thermal properties of pavement materials, (2) Increased evaporation for pavement, (3) Increased energy convection, and (4) Reduction of thermal energy on the surface or inside the pavement Li (2015)

\section{The role of trees and green spaces in urban environments}

Increasing the amount of vegetation is one of the most effective strategies in reducing the negative effects of UHI Alves and Lopes (2017). Plants have various effects on the urban environment. Regardless of the role of aesthetics and creating a sense of satisfaction with the urban environment, urban greenery improves air quality and reduces noise pollution and greenhouse gases. Trees and plants act as cooling agents in the urban environment through the process of evapotranspiration which leads to a reduction in energy consumption Santamouris (2014). The use of green roofs and walls in buildings increases the albedo and decreases the ambient temperature. The shade of trees with large crowns helps to reduce the temperature and also can be effective in protecting buildings and pedestrians' sidewalks from direct sunlight Sailor (2006).

\section{Urban forests and guidelines}

Urban forests have an impact on UHI and can be effective on mitigating the UHI effects Zhou et al. (2019). Trees with shading and evapotranspiration transfer a small part of the solar radiation to the ground, which can decrease the land surface temperature and leads to shape urban cool island Grimmond and Oke (1991), Rahman et al. (2017), Taha et al. (1988). UHI mitigation programs and guidelines are widespread: incentive programs, climate programs, development and training, resolutions, comprehensive programs and design guidelines, air quality standards, green building standards, etc. are among the various programs on this scale EPA (2014). Parking lots, plazas, private and public parks, and other urban areas that can be planted with trees are effective in reducing the negative impacts of UHI. Using tree-lined boulevards as an old solution can affect UHI Santamouris et al. (2004) 


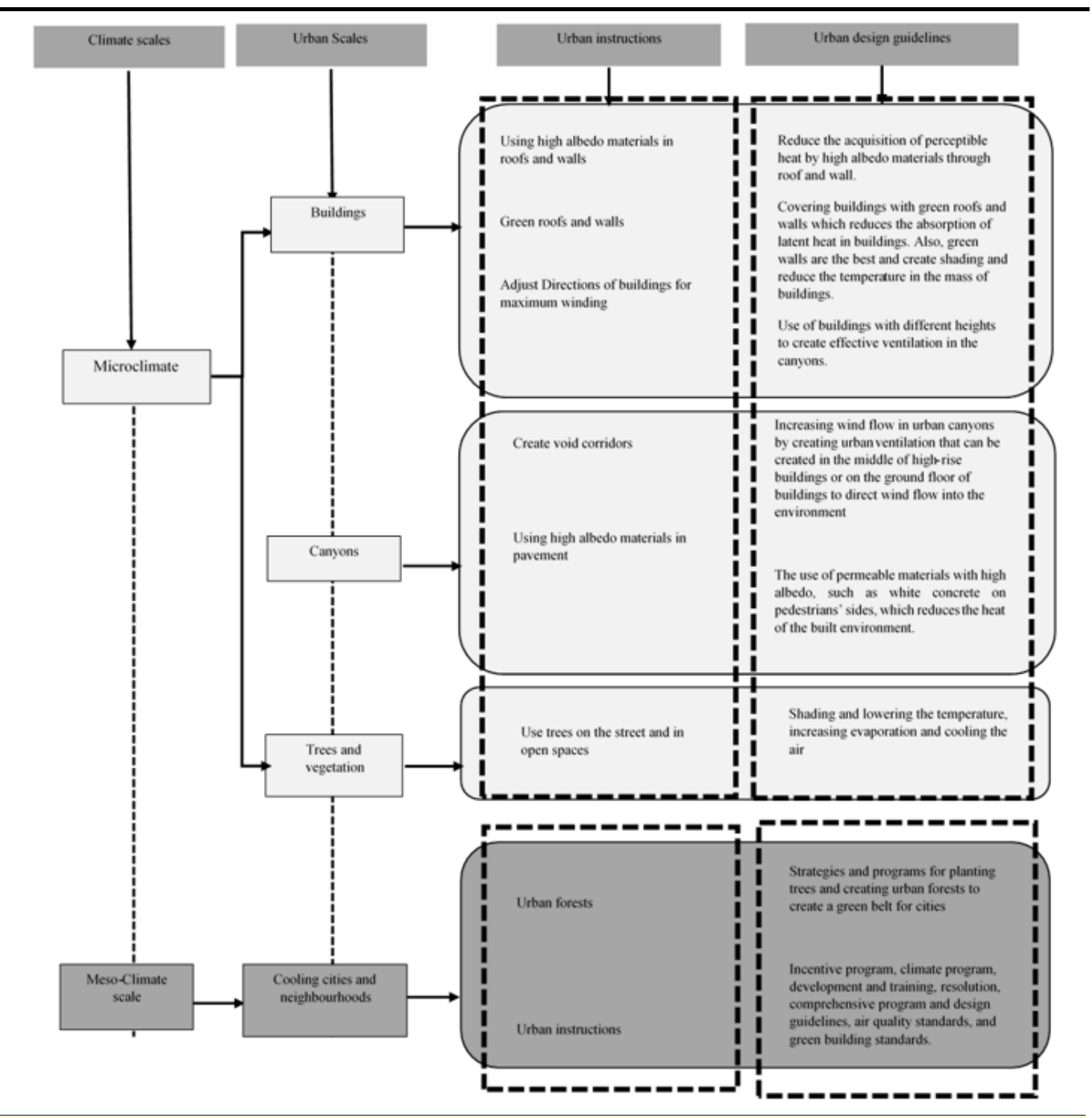

Figure 3 Various UHI mitigation strategies

Figure 4 shows the factors which affect UHI intensity. In urban areas, impermeable surfaces such as concrete and asphalt, high levels of air pollution and human activities, intensify the UHI Che-Ani et al. (2009). In addition, sidewalks and building walls are exposed to solar radiation during the day, absorbing heat, which increases air temperature during the day. Other similar urban elements also absorb heat during the day and night, followed by an increase in the temperature of the air and the creation of UHI. Generally, high buildings provide shading and reduce the temperature of the environment, but at the same time it absorbs solar radiation, and this allows the ambient temperature to be closely related to the urban environment Anand et al. (2015). 


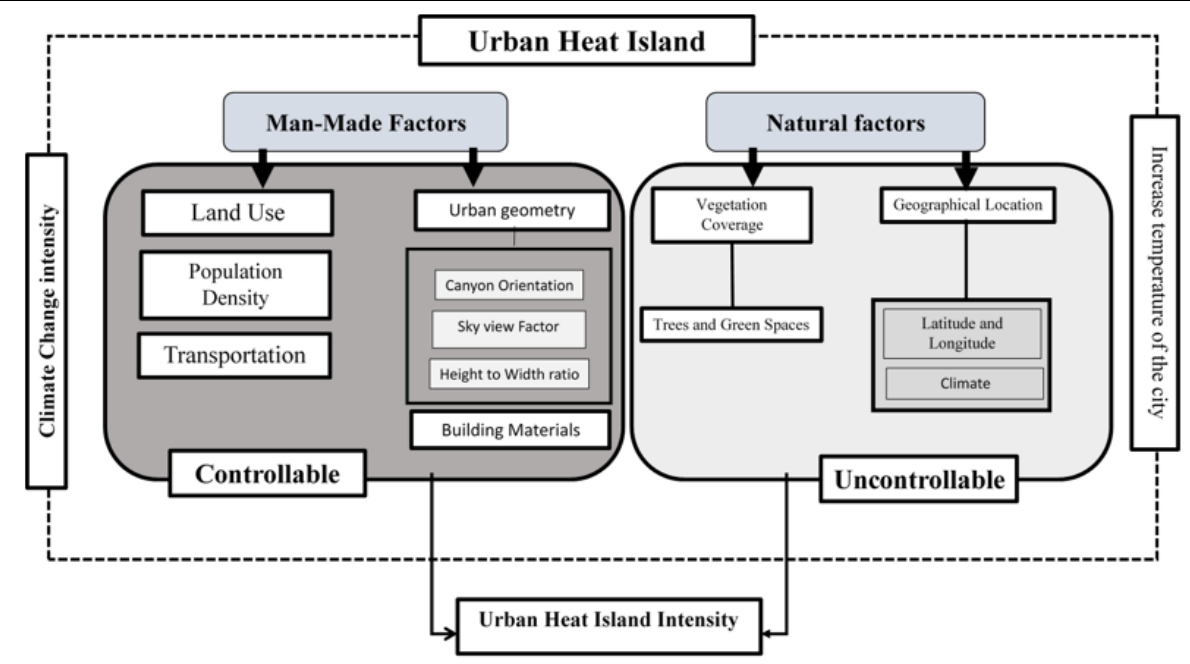

Figure 4 Factors affecting the intensification of UHI

\subsubsection{OUTDOOR THERMAL COMFORT}

The history of thermal comfort goes back to its use for military motives and the need for military work on ships and aircraft in high-temperature conditions Fabbri (2015). Thermal indices are a means of evaluating thermal environments to measure thermal comfort. In various studies, depending on the type of space, such as indoor or outdoor, thermal comfort has been assess using various methodologies. The concept of thermal comfort was introduced by Fanger in 1970 and was investigated in indoor spaces in various build types such as residential, offices and hospitals Fanger (1970). From 2003, thermal comfort has been studied in open spaces and since then, various studies have focused on open spaces in different climates Spagnolo and Dear (2003). Human body produces heat through metabolism, heat exchange with environment (mainly by radiation and convection), and heat loss by evaporation of body fluids. During relaxation and exercise, the heat transfer processes lead to changes in the temperature of vital organs Djongyang et al. (2010). Thermal comfort is related to how humans response to the thermal environment and includes physiological parameters such as sweating, heart rate, internal temperature, and skin temperature Dai (2014). Thermal comfort measurement indicators can be classified into two categories. Simple and experimental indicators that include several climatic elements, such ET ${ }^{1}, \mathrm{RT}^{2}, \mathrm{HOP}^{3}$, OP $^{4}$, WCI ${ }^{5}$ Ali-Toudert (2005), Oliver (2005), Yilmaz et al. (2013). The second category includes complex analytical classifications including PET 6 Höppe (1999), Matzarakis et al. (1999) ,SET7 Spagnolo and Dear (2003), PMV 8 Fanger (1970), UTCI $^{9}$ Bröde et al. (2012). The second category of models is based on energy balance (MEMI ${ }^{10}$ ); which can be calculated with complex mathematical formulas. The first approach in evaluating outdoor thermal comfort is to focus on human

1 Effective Temperature

2 Resultant Temperature

3 Humid Operative Temperature

4 Operative Temperature

5 Wind Chill Index

6 Physiological Equivalent Temperature

7 Standard Effective Temperature

8 Predicted Mean Vote

9 Universal Thermal Climate Index

10 Munich Energy Balance Model for Individuals 
thermal perception and sensation through various methods, including photographic comparison Cortesão et al. (2018) and questionnaire analysis Cohen et al. (2019). The second approach is to study thermal comfort according to the surrounding environment and the heat balance of the human body (Deng and Wong (2020), Wai et al. (2020). The MEMI approach is categorized into four sections: Outdoor thermal comfort and microclimate studies Fabbri et al. (2020), Zhen et al. (2020), outdoor thermal comfort and urban heat islands Evola et al. (2017), outdoor thermal comfort and urban areas Matallah et al. (2020), Ouali et al. (2020), Srivanit and Jareemit (2020), Wai et al. (2020), Zhu et al. (2020), outdoor thermal comfort and climate change Orosa et al. (2014). There are various tools to assess outdoor thermal comfort: (1) Envi-Met Bruse (1999), Rayman Matzarakis et al. (2007), SOLWEIG Katzschner and Thorsson (2009), TRNSYS Perini et al. (2017) STAR-CD Xuan et al. (2016), ANSYS Gupta et al. (2015), and TEB Jihad and Tahiri (2016). Table 2. show the main drawbacks of climatic models.

\begin{tabular}{|c|c|}
\hline Model & Limitation \\
\hline ANSYS & Cannot calculate outdoor thermal comfort indices \\
\hline STAR-CD & $\begin{array}{c}\text { Cannot calculate Predicted Mean Vote (PMV) and PET indices, and cannot assess } \\
\text { Standard Effective Temperature (SET) }\end{array}$ \\
\hline TEB & $\begin{array}{l}\text { Based on the assumption that all canyon directions of and wind directions have } \\
\text { equal probabilities. }\end{array}$ \\
\hline Envi-Met & $\begin{array}{l}\text { It is not a free software and do not affordable for low-come countries. } \\
\text { Free version covers a limit simulation area }\end{array}$ \\
\hline SOLWEIG & Cannot calculate wind flows Katzschner and Thorsson (2009) \\
\hline TRNSYS & $\begin{array}{l}\text { Limited capabilities in calculating MRT in canyons. } \\
\text { It is not a CFD program, so wind speed must be provided externally. TRNSYS is not } \\
\text { comparable to Envi-Met. } \\
\text { TRNSYS does not simulate trees and is not a suitable solution for shadow effects due } \\
\text { to the density and distribution of leaves. Perini et al. (2017) }\end{array}$ \\
\hline RayMan & $\begin{array}{l}\text { Developed by Matzarakis et al. (2000). It has a low execution time compared to CFD } \\
\text { software, and, like the SOLWEIG model, can calculate radiation and MRT, but this } \\
\text { calculation does not include reflections between buildings. }\end{array}$ \\
\hline
\end{tabular}

There are two approaches affecting thermal comfort (Figure 5), a) human factors consisting of the thermal balance approach of the human body, physical adaptation, and psychological adaptation, and b) environmental- climatic approaches that include air temperature, humidity, solar radiation, and wind.

\section{Human approaches}

The human body loses heat with a) evaporation from the skin that depends on humidity and the amount of wind flow around the body, b) convection which depends on the air temperature and the wind flow along the surface of the body (skin or clothing), c) radiation and d) conductivity Roaf et al. (2009). Radiation and conduction of heat exchange are through the environment, and during human normal position and exercise, heat transfer processes lead to a change in the temperature of vital organs of the body Djongyang et al. (2010). In order to reach comfort, human body should reach an energy balance that is calculated by equation Equation 1.

$$
\mathrm{M} \pm \mathrm{Rd} \pm \mathrm{C}_{-} \mathrm{E}= \pm \mathrm{S}
$$

Equation 1

Where $M$ is the amount of metabolic rate, $\mathrm{R}$ and $\mathrm{C}$ are heat exchanges through radiation and convection, $E$ is heat loss through perspiration, $S$ is heat storage in the 
body. Positive $\mathrm{S}$ indicates an energy gain for the body and a negative $\mathrm{S}$ means losing energy. If $\mathrm{S}$ is zero, the thermal stress is minimal. Thermal comfort is combination of several climatic variables. To determine comfort and discomfort, it is necessary to know the biological indicators of meteorology and predict human response to physiological stresses Oliver (2005).

\section{Physical adaptation approach}

The physical adaptive approach was defined by Nikolopoulou et al. (1999). Adaptation is actually a set of individual reactions to achieve comfortable conditions by reducing or increasing the level of activity and clothing or by environmental interference Fabbri (2015). In order to meet needs, humans adapt themselves with the environmental changes through reactive and interactive adaptation. Reactive approach includes changing the level of clothing or activity and even relocating to reach thermal comfort. Interactive approache can also be a set of measures to improve the thermal situation, such as opening a window. Such physical adaptations in open spaces have many limitations due to the character of the open spaces Nikolopoulou et al. (1999).

\section{Psychological adaptation approach}

Psychological approach to thermal comfort plays an important role both indoors and outdoors. When people are told that the surrounding air is warm, they feel warm and vice versa Höppe (2002). The effects of psychological approach are extracted from individuals using a questionnaire. Various psychological parameters of outdoor thermal comfort include naturalness, experiences (long-term / shortterm), the duration of exposure to the environment, control of perception, and environmental stimuli Nikolopoulou and Steemers (2003). The effects of these parameters individually and the weight and importance of each of these factors on outdoor thermal comfort have not been determined yet.

\section{Climatic factors}

Various environmental parameters such as climate and artificial environment affect the outdoor thermal comfort. There are four main climatic factors that affect outdoor thermal comfort,

a) air temperature as the most commonly indicator used for thermal comfort evaluation. Air temperature is actually the dry temperature that can be measured with a thermometer. Absorption or dissipation of heat from the body is directly related to ambient temperature. So, when the ambient temperature increases, people feel warm and if it decreases, they feel cold.

b) The human body receives solar radiation in three different ways: directly, diffused through clouds and airborne water vapor, and lastly reflected from objects in the environment, e.g., buildings and ground. Mean radiant temperature (MRT) is an indicator calculated to measure the interactions of human body with its surrounding environment in terms of radiations. When MRT is higher than the temperature of the exposed skin (or that of the outer layer of clothing), there is a radiative heat gain Johansson (2006). Tmrt (in $\mathrm{K}$ ) in outdoors is calculated by the Equation 2

$$
T_{m r t}=\left[\frac{1}{\sigma}+\left(\sum_{i=1}^{n} E_{i} F_{i}+\frac{a k}{\varepsilon \mathrm{p}} \sum_{i=1}^{n} D_{i} F_{i}+\frac{a k}{\varepsilon \mathrm{p}} f p I\right)\right]
$$

Equation 2

$E i$ is the long-wave radiation component, Di is the diffusely reflected shortwave radiation, and $F i$ is the angle weighting factor. $I$ am the direct solar radiation impinging normal to the surface and $f_{p}$ is the surface projection factor, which is a 
function of the sun's position and the body posture. $a_{k}$ is the absorption coefficient of the irradiated body surface for short-wave radiation ( $\sim 0.7), \varepsilon_{\mathrm{p}}$ is the emissivity of the human body $(\sim 0.97)$, and $\sigma$ is the Stefan-Boltzmann constant $\left(5.67 .10^{-8} \mathrm{~W} / \mathrm{m}\right.$ $\left.{ }^{2} \mathrm{~K}^{4}\right)$.

c) Wind is one of the climatic factors affecting outdoor thermal comfort. Built environments and trees, have a great effect on changing wind direction and flow Yasa (2016). Buildings have the ability to modify the wind and increase or decrease its mechanical effects. Vegetation can also reduce wind speed and even change its direction Aljawabra (2014). According to Wilson and Wise (2007), wind comfort with an average wind speed of $5 \mathrm{~m} / \mathrm{s}$ is suitable for all activities in open urban environments, wind speeds higher than $15 \mathrm{~m} / \mathrm{s}$ can be dangerous for pedestrians Willemsen and Wisse (2007).

d) Relative Humidity is the amount of water vapor in the air, which is expressed with percentage. Humidity levels lower than $30 \%$, cause dryness of the respiratory system and eye sensitivity and even allergies. Also, decreasing relative humidity can increase some viral infections. If the humidity is more than $60 \%$, it will increase the growth of bacteria in humid environments Arundel et al. (1986). Therefore, an appropriate level of relative humidity, leads to better comfort situation and also promotes health. Humidity has little effect on thermal comfort in cold weather, while in hot conditions in order to maintain thermal comfort, the human body needs to increase heat loss by reducing clothing and sweating, which causes heat loss through perspiration. Evaporation decreases with increasing relative humidity.

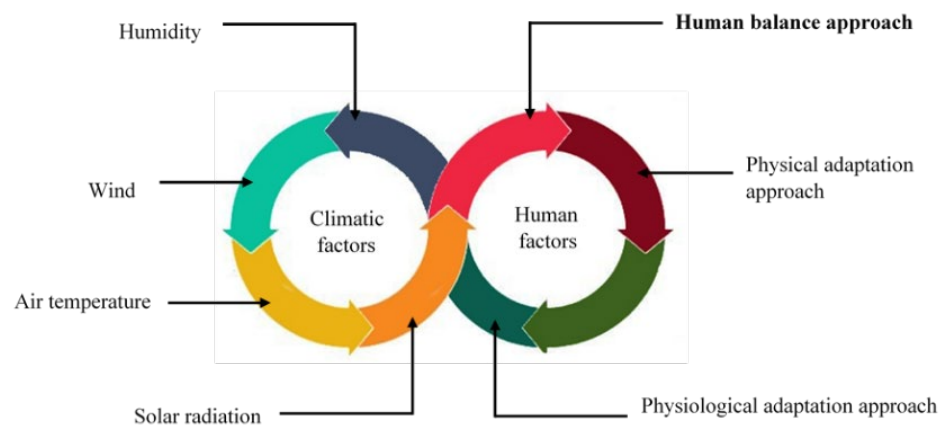

Figure 5 various approaches affecting thermal comfort

\subsubsection{URBAN FORM}

Urban forms are influenced by the environment, economic development, social and political life Bramley and Kirk (2005). There are some multidisciplinary approaches to urban form (Figure 3). Urban form has various definitions and aspects. Urban planning NRTEE (2003), Maller (1998), Moughtin (2003), Oliveira (2016), Zaker et al. (2010), urban form Dai (2014), Irger (2014), Kropf (1993), social pattern Cuthbert and Anderson (2002), Tsai (2005), physical and climate Dempsey et al. (2010), and physical and economic Clifton et al. (2008) are the various aspects of urban form (Figure 6). Cities experience specific climatic conditions, and this occurs due to the difference in weather conditions (air temperature, humidity, wind speed, wind direction, rainfall) compared to less densely populated areas Lilly and Devadas (2009). Urban form is a factor that determines urban climate and environmental temperature Arnfield (2003), Jamei et al. (2016), Oke (1988), Santamouris et al. (2004), According to Ünlü (2011), urban form components are building height, plot cover, parcels, block scale, block 
shape, and FAR Ünlü (2011) that have effects on ambient temperature. Urban form parameters also can be defined with height to width $(\mathrm{H} / \mathrm{W})$ ratio Rodríguez et al. (2016), sky view factor (SVF), building materials, roof and ground cover which affect urban climate Jamei et al. (2016). Due to exposure to solar radiation and wind flow, the urban form has a significant effect on air temperature Krüger et al. (2011). In addition, design parameters such as building materials, thermal mass, plants, water, shade types or sunlight control also have an impact on the reduction of urban ambient temperatures Abreu-Harbich et al. (2014), Esther and Sagada (2014), Georgi and Tzesouri (2008). Materials in urban forms have an impact on the environment due to the absorption of solar radiation and can reduce ambient temperature Akbari et al. (1997). According to Shahmohamadi et al. (2011), the heat emission from dark colors increases the ambient temperature to $7{ }^{\circ} \mathrm{C}$, while the brighter colors change the temperature from $2{ }^{\circ} \mathrm{C}$ to $3{ }^{\circ} \mathrm{C}$ Shahmohamadi et al. (2011). Thus, the form of the built environment is one of the most important parameters affecting the temperature of the environment Horrison and Amirtham

(2016).
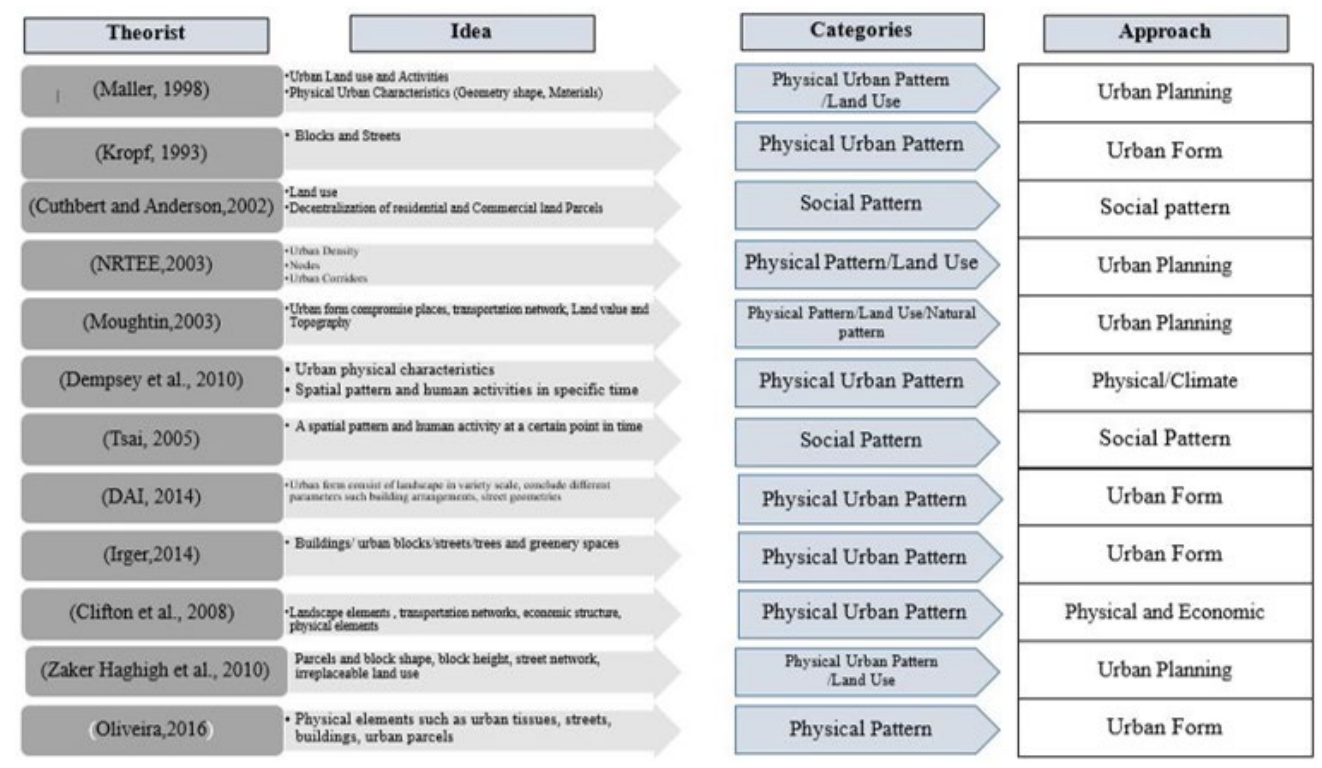

Figure 6 various urban form categories

\section{RESULTS}

The effects of UHI on outdoor thermal comfort are divided into four categories. The first category of studies includes studies of the spatial development of thermal comfort in the city, which has tried to identify the effects of local UHI on human health, outdoor thermal comfort, and energy consumption. Gupta et al. (2015). The second category of studies includes the evaluation of changes in outdoor thermal comfort in open spaces in specific places Deng and Wong (2020), Mi et al. (2020). The third category is studies of outdoor thermal comfort in specific climatic situations Lam et al. (2020), Shashua-Bar et al. (2019). Extensive studies have been conducted in different climates to investigate outdoor thermal comfort. Most of these studies evaluate outdoor thermal comfort in the summer. The last category discusses the future state of outdoor thermal comfort in a specific location due to heat and climate change Roshan et al. (2019). For example, predictions in Sweden show that increasing building density during the years 2080-2099 will increase external thermal comfort. Urban geometry will affect the average radiant 
temperature and can lead to reduction of thermal stress in cities. Also, the scenarios show a climate that towards the end of the present century, temperatures will rise, and climatic comforts will increase significantly in winter Thorsson et al. (2011). UHI is a phenomenon that affects people's health Gupta et al. (2015). Recent studies indicate a linkage between diseases, climate change and global warming. Thus, as the heat of the earth increases, the intensification of the UHI also rises, so it can be said that climate change is affecting UHI and the environment of human life Roaf et al. (2009) In addition, UHI intensity leads to an increase in ambient temperatures and has an adverse effect on the presence of pedestrians in open urban environments and human health Akbari and Konopacki (2004). WHO shows that high temperatures affect mortality rates (WHO, 2007)? The effects of temperature increase can also be seen on other living organisms, as plants, animals and the spread of viruses and bacteria are as well affected by it. As temperatures rise, microorganisms activate and cause diseases Yow (2007), Hajat et al. (2006). Reports show higher heatstroke related hospital admissions and increased mortality rates during heat waves and environmental temperature increases Pirard et al. (2005). According to Analitis et al. (2008) with $1{ }^{\circ} \mathrm{C}$ increase of the ambient temperature, the mortality rate increased by $1.35 \%, 1.72 \%$ in cardiovascular disease, $3.30 \%$ in respiratory problems and $1.25 \%$ in cerebral complications Analitis et al. (2008). Increasing temperature also affects other human health sectors, as people who live in urban warm environments suffer from higher rates of digestive system diseases Rajagopalan et al. (2014) UHI and temperature rising not only cause physical problems, but also mental health issues and lead to nervous system diseases, insomnia, irritability, depression, and memory loss Yang et al. (2016) Normal body comfort temperature is between $36.5^{\circ} \mathrm{C}$ and $37.5^{\circ} \mathrm{C}$, skin temperature is $30^{\circ} \mathrm{C}$, in the head and body between $34^{\circ} \mathrm{C}$ and $35^{\circ} \mathrm{C}$, without sweating Hensel (1981). As this temperature rises, the amount of sweating increases and its adverse effects on the health of the body and soul increase. Figure 7. shows the urban form parameters affecting Urban Heat Island.

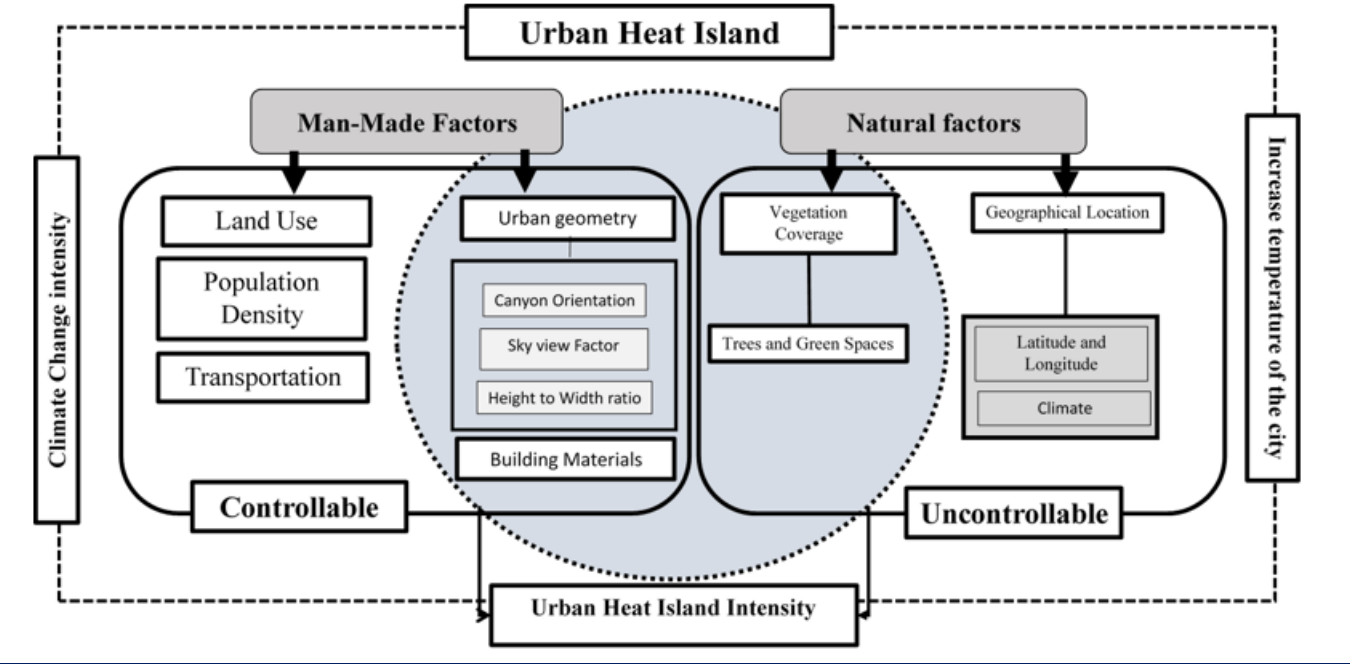

Figure 7 Urban form parameters affecting Urban Heat Island

\section{DISCUSSION OF RESULTS}

Adding shading with H/W ratios Kedissa et al. (2016), Muniz-Gäal et al. (2020), vegetation (such as trees) Davtalab et al. (2020), Lee and Jim (2019), Lobaccaro and Acero (2015), Shashua-Bar et al. (2011), canyon orientation Baruti et al. (2019), Rui et al. (2019), Vasilikou and Nikolopoulou (2019), Zhang et al. (2017), and thermal features of urban surfaces Lee and Mayer (2018) are four factors improving outdoor 
thermal comfort. Urban form effect on UHI and these results are agreement with Zhou et al. (2017) Figure 8. shows urban form factors that affect UHI intensity.

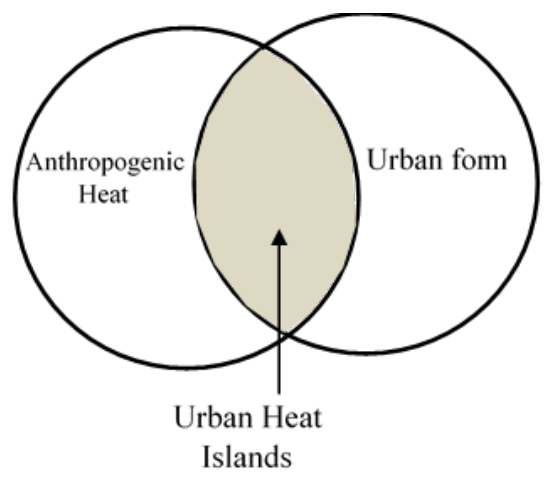

Figure 8 Urban form factors effect on UHI

Urban Heat Islands = Anthropogenic Heat + Urban Structure Factor

Interactions of UHI, urban form and outdoor thermal comfort are shown in Figure 9. These keywords have an effect on outdoor thermal comfort.

\section{Decent urban form = outdoor thermal comfort improvement}

Reducing UHI intensity is the precursor of enhancing outdoor thermal comfort. Thus, there is an inverse relationship between outdoor thermal comfort and UHI significantly during daytime. In other words, where UHI intensifies, outdoor thermal comfort deteriorates and vice versa. These results are agreement with Qaid et al. (2016) that showed UHI, and outdoor thermal comfort are important during design process. The urban forms have an impact on the reduction or intensification of UHI and the outdoor thermal comfort, which means that not only urban form could.

Lack of Appropriate Urban Form parameters + Urban Heat Island Intensity $=$ Decrease Outdoor Thermal Comfort

form could reduce UHI effects, but also could enhance outdoor thermal comfort.

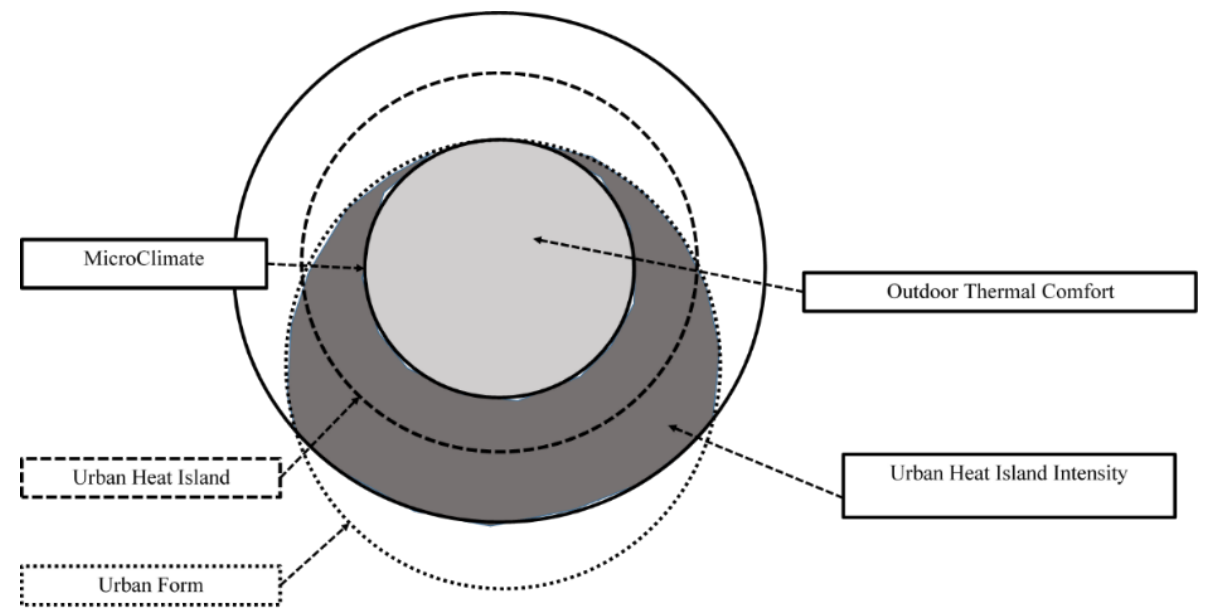

Figure 9 Influencing Factors on outdoor Thermal Factor and Communication between Keywords 


\section{CONCLUSION}

This study aimed to present a comprehensive view to urban heat islands, urban form and outdoor thermal comfort and also confine an ideal model of outdoor thermal comfort. Regarding the literatures studied, a few conclusions were assimilated as follows:

\section{H/W ratio}

In Figure 10. the $\mathrm{H} / \mathrm{W}$ ratio is shown, which is also known as the dimensional ratio, and is actually derived from two variables: the average height of the building or the wall next to the canyon and the canyon width (the wall-to-wall distance across the canyon) Oke (1982). In terms of outdoor thermal comfort several studies (AliToudert and Mayer (2006), Hwang et al. (2011), Yang et al. (2015) show that when $\mathrm{H} / \mathrm{W}$ ratio increases, the solar radiation is blocked and the shading at street level increases, decreasing thermal stresses. Although, high $\mathrm{H} / \mathrm{W}$ ratio decrease wind flowing and vice versa Yahia et al. (2017), the H/W ratio is still one of the important components of urban form, which has a great effect on the outdoor thermal comfort.

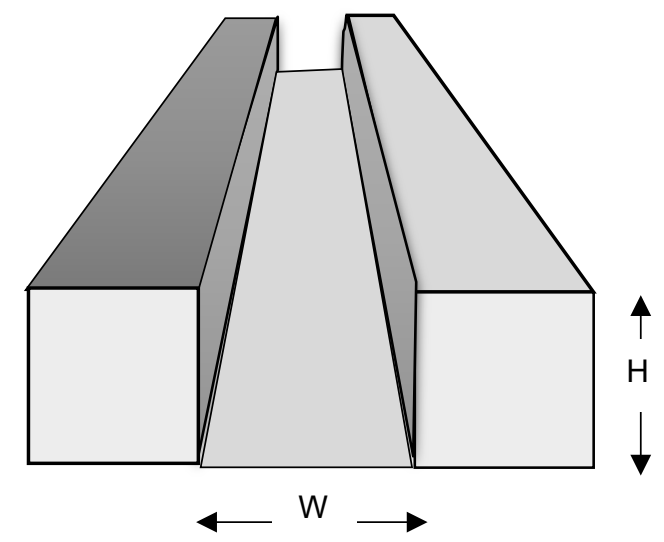

Figure 10 The height-width $(\mathrm{H} / \mathrm{W})$ ratio

\section{Canyon Orientation}

The orientation of street canyons also affects the environmental conditions in cities. The shape of the canyon has a great effect on outdoor thermal comfort. Its impact on human health and energy consumption is effective in buildings located in urban environments Ali-Toudert and Mayer (2006). Among urban design parameters, $\mathrm{H} / \mathrm{W}$ ratio and urban canyon orientation have the most influence on urban microclimate. The canyon orientation is simply described by cardinal direction such as N-S, E-W, and NW-SE, NE-SW. Effects of various canyon orientations on outdoor thermal comfort is different in various climates and it is the main factor in evaluating thermal comfort in combination with different $\mathrm{H} / \mathrm{W}$ ratio.

\section{Urban Materials and Surfaces}

In the past, and especially in the hot and dry climate, there was a lot of attention to creating shadows in pedestrian walkways and the use of indigenous materials to decrease sunlight absorption, which had a significant effect on outdoor thermal comfort. Moreover, building materials have an impact on microclimate Johansson (2006). The thermal properties of the materials used in the urban fabric enrich the differences in the cooling rates generated by the different urban geometries Rose et al. (2011).

\section{Vegetation}


Planting vegetation improves the urban environment. The cooling effect of trees is higher during summers, but this effect is negligible in winter due to lower evaporation Tong et al. (2017). Trees in the winter reduce wind speed and create thermal comfort. Outdoor thermal comfort studies demonstrate that tree-planting increases shading and thermal comfort Tong et al. (2017). Deciduous trees with dense crowns are almost impermeable and allow only 1-5\% of the direct solar radiation and between $8-15 \%$ of the total radiance reach the ground surfaces. In winter, the radiance transfer is low. Leafless trees block $48 \%-60 \%$ of the solar radiation. In warm climates, the location of trees plays an important role in increasing outdoor thermal comfort and reducing annual energy consumption. In colder climates and in cities at high altitudes, trees have a significant effect on reducing heat stress in summer Konarska et al. (2014).

This paper surveys the relationship between UHI, urban form and outdoor thermal comfort. Figure 11 shows urban form parameters that effect outdoor thermal comfort.

The Figure 11 gives a comprehensive study of measuring outdoor thermal comfort, the $\mathrm{H} / \mathrm{W}$ ratio, vegetation and trees, open spaces, building roofs and façade materials, and canyon orientation. Climatic parameters such as relative humidity, air temperature, and wind velocity and direction should be accompanied by these parameters. According to the software specified in this model, it is possible to consider different indices that measure thermal comfort. The choice of the type of urban form parameter and effects on outdoor thermal comfort as well as software and indices for measuring outdoor thermal comfort goes back to the logic of researchers in this field, which can be determined according to the needs of the researcher. This model can be used for future research in outdoor thermal comfort and can be used to assess urban form effects on outdoor thermal comfort.

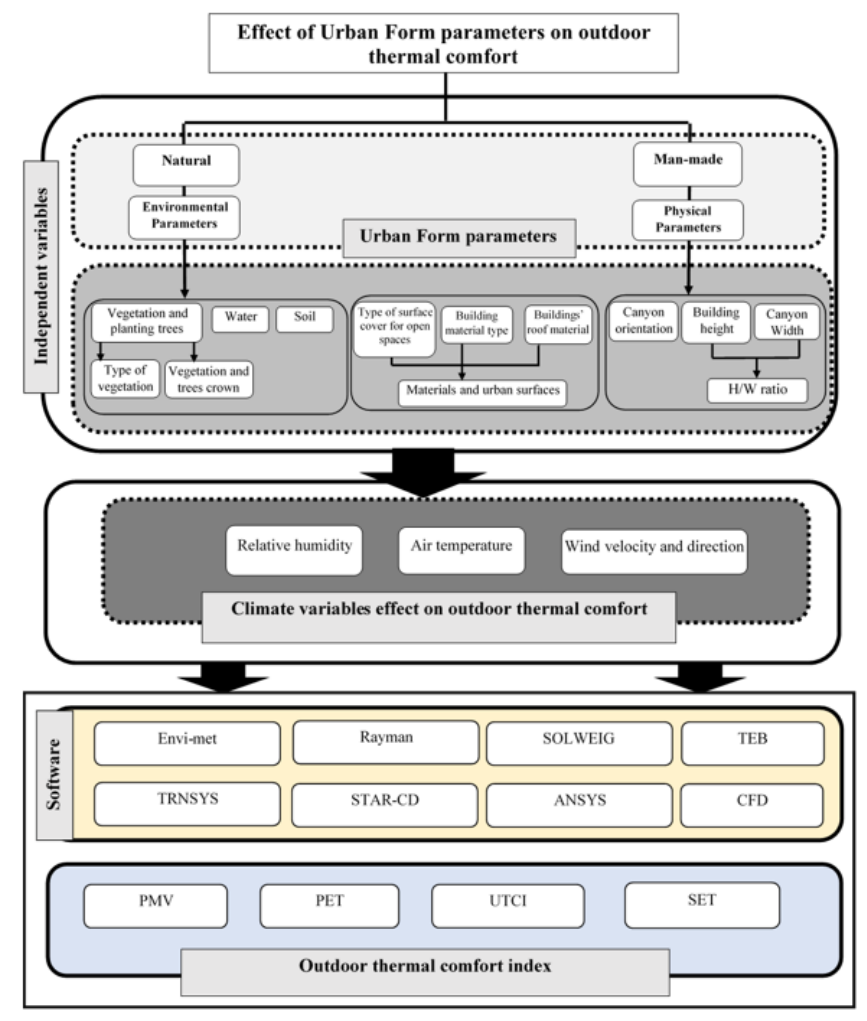

Figure 11 Ideal model for the evaluating outdoor thermal comfort 


\section{REFERENCES}

Aboelata, A., \& Sodoudi, S. (2020). Evaluating the effect of trees on UHI mitigation and reduction of energy usage in different built up areas in Cairo. Building and Environment, 168, 106490. doi : Retrieved from https://doi.org/10.1016/j.buildenv.2019.106490

Abreu-Harbich, L. V., Labaki, L. C., \& Matzarakis, A. (2014). Thermal bioclimate in idealized urban street canyons in Campinas, Brazil Theoretical and Applied Climatology, 115(1-2), 115-223. doi : Retrieved from https://doi.org/10.1007/s00704-013-0886-0

Berdahl, P., Akbari, H., and Rose, L. S. (2002) Aging of reflective roofs : soot deposition. Applied optics, 41(12), 2355-2360. doi : Retrieved from https://doi.org/10.1364/A0.41.002355

Akbari, H. (2005). Energy Saving Potentials and Air Quality Benefits of Urban HeatIslandMitigation : Lawrence Berkeley National Laboratory: Lawrence Berkeley National Laboratory

Akbari, H., \& Konopacki, S. (2004). Energy effects of heat-island reduction strategies in Toronto, Canada. Energy, 29(2), 191-210. doi: Retrieved from https://doi.org/10.1016/j.energy.2003.09.004

Akbari, H., Bretz, S., Kurn, D. M., \& Hanford, J. (1997). Peak power and cooling energy savings of high-albedo roofs. Energy and Buildings, 25(2), 117-126. doi: Retrieved from https://doi.org/10.1016/S0378-7788(96)01001-8

Akbari, H., Pomerantz, M., \& Taha, H. (2001). Cool surfaces and shade trees to reduce energy use and improve air quality in urban areas. Solar Energy, 70(3), 295310. doi: Retrieved from https://doi.org/10.1016/S0038-092X(00)00089$\mathrm{X}$

Ali-Toudert, F. (2005). Dependence of Outdoor Thermal Comfort on Street Design in Hot and Dry Climate. (PhD Thesis), institute of meteorology, Freiburg.

Ali-Toudert, F., \& Mayer, H. (2006). Numerical study on the effects of aspect ratio and orientation of an urban street canyon on outdoor thermal comfort in hot and dry climate. Building and Environment, 41(2), 94-108. doi: Retrieved from https://doi.org/10.1016/j.buildenv.2005.01.013

Aljawabra, F. F. (2014). Thermal comfort in outdoor urban spaces: the hot arid climate. (Doctor of Philosophy), University of Bath,

Alves, E., \& Lopes, A. (2017). The Urban Heat Island Effect and the Role of Vegetation to Address the Negative Impacts of Local Climate Changes in à Small Brazilian City. Atmosphere, 8, 1-14. doi : Retrieved from https://doi.org/10.3390/atmos8020018

Amirtham, L. R. (2010). Effect of urbanization on urban heat island and thermal comfort in chennai metropolitan area,India. (Doctora of philosophy), Chenanai,

Analitis, A., Katsouyanni, K., Biggeri, A., Baccini, M., Forsberg, B., Bisanti, L., . . . Michelozzi, P. (2008). Effects of Cold Weather on Mortality: Results From 15 European Cities Within the PHEWE Project. 168(12), 1397-1408. doi: Retrieved from https://doi.org/10.1093/aje/kwn266

Anand, P., gupta, S., \& Shashwat, S. (2015). Improvement of outdoor thermal comfort for a residential development in Singapore. 2076-2909, 6. Retrieved from https://www.proquest.com/openview/fce80a0f02012ef678450978201cf 278/1?pq-origsite=gscholar\&cbl=2037639

Arnfield, J. (2003). Two decades of urban climate research: A review of turbulence, exchanges of energy and water, and the urban heat island. International 
Journal of Climatology, 23(1), 1-26. doi : Retrieved from https://doi.org/10.1002/joc.859

Arundel, A. V., Sterling, E. M., Biggin, J. H., \& Sterling, T. D. (1986). Indirect Health Effects of Relative Humidity in Indoor Environments Environmental health perspectives, 65, 351-361. Retrieved from https://doi.org/10.1289/ehp.8665351

Baruti, M. M., Johansson, E., \& Åstrand, J. (2019). Review of studies on outdoor thermal comfort in warm humid climates: challenges of informal urban fabric. International Journal of Biometeorology, 63(10), 1449-1462. doi: Retrieved from https://doi.org/10.1007/s00484-019-01757-3

Battisti, A., Laureti, F., Zinzi, M., \& Volpicelli, G. (2018). Climate Mitigation and Adaptation Strategies for Roofs and Pavements : A Case Study at Sapienza University Campus. Sustainability, 10, 3788. doi :10.3390/su10103788 Retrieved from https://doi.org/10.3390/su10103788

Bramley, G., \& Kirk, K. (2005). Does Planning Make a Difference to Urban Form ? Recent Evidence from Central Scotland. Environment and Planning A : Economy and Space, 37(2), 355-378. doi : Retrieved from https://doi.org/10.1068/a3619

Bruse, M. (1999). Simulating microscale climate interactions in complex terrain with a high- resolution numerical model : A case study for the Sydney CBD Area (Model Description). Paper presented at the International Conference on Urban Climatology \& international congress of biometeorology, Sydney. www.envi-met.net

Bröde, P., Fiala, D., \& Błażejczyk, K. (2012). Deriving the operational procedure for the Universal Thermal Climate Index (UTCI). International Journal of Biometeorology, 56, 481-494. doi : Retrieved from https://doi.org/10.1007/s00484-011-0454-1

Che-Ani, A. I., Shahmohamadi, P., Sairi, A., Mohd-Nor, M. F. I., Sain, M. F. M., \& Surat, M. (2009). Mitigating the urban heat island effect: Some points without altering existing city planning. European Journal of Scientific Research, 35(2), 204-216. Retrieved from https://d1wqtxts1xzle7.cloudfront.net/24739653/ejsr_35_2_06-withcover-page-v2.pdf?Expires=1644302914\&Signature=XFWD0VuCvkGr8LLlHlabJLy1whe-RlEdrTIwiQytMPt-neZNyQIyXPDD4-

YUYHjj4J4b eN1MM70Nge2kskmn0N3E7Zs6HHJdwADQPTFzuk5b3KyoR00n-UNE19Iv9VcI6CtidebDIiM fkuseBTp4pp9yb0MTvy6LJ3m9v5PJRJLHHkox8I xlyFZ1t0TSKQZgatU8lp4hrdkhK

G 4GDhwYBLylqwu56dOuCECNGyDu cvDW 08MaSobZJSibAarrqcnH0b AP6jKHNaAAZ1t0Fn9w 8A00z7Nxi9xQsBKe4TfO0nt sy7VnP61XxP7cH BKOCuF4vMAQCmUAsQ_\&Key-Pair-Id=APKAJLOHF5GGSLRBV4ZA

Chen, R., \& You, X.-y. (2020). Reduction of urban heat island and associated greenhouse gas emissions. Mitigation and Adaptation Strategies for Global Change, 25(4), 689-711. doi : Retrieved from https://doi.org/10.1007/s11027-019-09886-1

Clifton, K., Ewing, R., Knaap, G. J., \& Song, Y. (2008). Quantitative analysis of urban form : à multidisciplinary review. Journal of Urbanism: International Research on Placemaking and Urban Sustainability, 1(1), 17-45. doi: Retrieved from https://doi.org/10.1080/17549170801903496

Cohen, P., Shashua-Bar, L., Keller, R., Gil-Ad, R., Yaakov, Y., Lukyanov, V., . . Potchter, O. (2019). Urban outdoor thermal perception in hot arid Beer Sheva, Israel: 
Methodological and gender aspects. Building and Environment, 160, 106169. doi: Retrieved from https://doi.org/10.1016/j.buildenv.2019.106169

Cortesão, J., Brandão Alves, F., \& Raaphorst, K. (2018). Photographic comparison: à method for qualitative outdoor thermal perception surveys. International Journal of Biometeorology. doi: Retrieved from https://doi.org/10.1007/s00484-018-1575-6

Cuthbert, A. L., \& Anderson, W. P. (2002). An examination of urban form in HalifaxDartmouth : Alternative approaches in data. In Canadian Journal of Urban Research, 11(2), 213 -237

Dai, Q. (2014). The Impact of Urban Form on Thermal Comfort across Street Zones. (Doctor of Philosophy), The Chinese University of Hong Kong,

Davtalab, J., Deyhimi, S. P., Dessi, V., Hafezi, M. R., \& Adib, M. (2020). The impact of green space structure on physiological equivalent temperature index in open space. Urban Climate, 31, 100574. doi: Retrieved from https://doi.org/10.1016/j.uclim.2019.100574

Dempsey, N., Brown, C., Raman, S., Porta, S., Jenks, M., Jones, C., \& Bramley, G. (2010). Elements of Urban Form. Dordrecht : Springer Netherlands.

Deng, J.-Y., \& Wong, N. H. (2020). Impact of urban canyon geometries on outdoor thermal comfort in central business districts. Sustainable Cities and Society, 53, 101966. doi: Retrieved from https://doi.org/10.1016/j.scs.2019.101966

Djongyang, N. l., Tchinda, R., \& Njomo, D. (2010). Thermal comfort: A review paper. Renewable and Sustainable Energy Reviews, 14(9), 2626-2640. doi: Retrieved from https://doi.org/10.1016/j.rser.2010.07.040

EPA. (2014). Reducing Urban Heat Islands: Compendium of Strategies Urban Heat Island Basics. Retrieved from USA :

Erell, E., Pearlmutter, D., \& Williamson, T. J. (2011). Urban Microclimate: Designing the Spaces Between Buildings: Taylor \& Francis. Retrieved from https://doi.org/10.4324/9781849775397

Esther, M. M., \& Sagada, M. L. (2014). An Evaluation Of Thermal Comfort Conditions In An Urban Entertainment Centre In Hot-Dry Climate Of Nigeria. International Journal of Energy and Environmental Research, 2(1), 55-74. Retrieved from https://d1wqtxts1xzle7.cloudfront.net/50525229/published_journal_Esth er_Malgwi_Dr._Sagada-with-cover-page-

v2.pdf?Expires=1644303050\&Signature=UxwUKYMCdExoWq25DDq5LiXS ZsAHoSk09prDjKeNpUjWKkw1Z3yNwJBg1Im875ki5ciDMElkZNZwDwuQ R6H2esGhwnDJ50Jn9SIIQmQPA47Tbf8 hf3ze5lIUNqMLshXVwKLnl40flm rPm1uqPOc-Bjsxe2XpbdDm0jOIPGwQvJTRWg3IkqgbV1ZfmPsGvVZ0WiaC4YswRdxwApj5L82bkVXTUnYHS8fS2rMXz5yaPKTDrQ FwLbU1d2kOh5zMuthNGa3zhx2U5LH2G0VvHhWbrpYsxfCGCg95Iyr9sf85IcGoW7oupbl33pXsxteKrvwcYDEJkHMhuUyKz5e53w_\&Key-PairId=APKAJLOHF5GGSLRBV4ZA

Evola, G., Gagliano, A., Fichera, A., Marletta, L., Martinico, F., Nocera, F., \& Pagano, A. (2017). UHI effects and strategies to improve outdoor thermal comfort in dense and old neighbourhoods. Energy Procedia, 134, 692-701. doi: Retrieved from https://doi.org/10.1016/j.egypro.2017.09.589 
Fabbri, K. (2015). Indoor Thermal Comfort Perception : A Questionnaire Approach Focusing on Children. Switzerland : Springer International Publishing. Retrieved from https://doi.org/10.1007/978-3-319-18651-1

Fabbri, K., Ugolini, A., Iacovella, A., \& Bianchi, A. P. (2020). The effect of vegetation in outdoor thermal comfort in archaeological area in urban context. Building and Environment, 175, 106816. doi: Retrieved from https://doi.org/10.1016/j.buildenv.2020.106816

Fanger, P. (1970). Thermal comfort. Analysis and applications in environmental engineering.

Galal, O. M., Mahmoud, H., \& Sailor, D. (2020). Impact of evolving building morphology on microclimate in a hot arid climate. Sustainable Cities and Society, 54, 102011. doi : Retrieved from https://doi.org/10.1016/j.scs.2019.102011

Georgi, N., \& Tzesouri, A. (2008). Monitoring Thermal Comfort in Outdoor Urban Spaces for Bioclimatic Conditions Improvement. Paper presented at the 1st WSEAS International Conference on LANDSCAPE ARCHITECTURE, Portugal. www.wseas.us

Ghasemi, Z., Esfahani, M. A., \& Bisadi, M. (2015). Promotion of Urban Environment by Consideration of Human Thermal \& Wind Comfort : A Literature Review. Procedia - Social and Behavioral Sciences, 201, 397-408. doi : Retrieved from https://doi.org/10.1016/j.sbspro.2015.08.193

Grimmond, C. S. B., \& Oke, T. R. (1991). An evapotranspiration-interception model for urban areas. 27(7), 1739-1755. doi: Retrieved from https://doi.org/10.1029/91WR00557

Gupta, S., Anand, P., \& Shashwat. (2015). Improvement of outdoor thermal comfort for a residential development in Singapore. International Journal of Energy and Environment (IJEE), 6(6), 567-586. Retrieved from https://www.proquest.com/openview/fce80a0f02012ef678450978201cf 278/1?pq-origsite=gscholar\&cbl=2037639

Hajat, S., Armstrong, B., Baccini, M., Biggeri, A., Bisanti, L., Russo, A., ... Kosatsky, T. (2006). Impact of High Temperatures on Mortality: Is There an Added Heat Wave Effect? Epidemiology, 17(6), 632-638. doi: Retrieved from https://doi.org/10.1097/01.ede.0000239688.70829.63

Hensel, H. (1981). Thermoreception and Temperature Regulation London, New York Academic Press.

Horrison, E., \& Amirtham, L. (2016). Role of Built Environment on Factors Affecting Outdoor Thermal Comfort - A Case of T. Nagar, Chennai, India. Indian Journal of Science and Technology, 9(5), 1-4. doi : Retrieved from https://doi.org/10.17485/ijst/2016/v9i5/87253

Huang, H., Yang, H., Deng, X., Zeng, P., Li, Y., Zhang, L., \& Zhu, L. (2019). Influencing Mechanisms of Urban Heat Island on Respiratory Diseases. Iranian journal of public health, 48(9), 1636-1646. doi: Retrieved from https://doi.org/10.18502/ijph.v48i9.3023

Hwang, R.-L., Lin, T.-P., \& Matzarakis, A. (2011). Seasonal effects of urban street shading on long-term outdoor thermal comfort. Building and Environment, 46(4), 863-870. doi: Retrieved from https://doi.org/10.1016/j.buildenv.2010.10.017

Höppe, P. (1999). The physiological equivalent temperature-a universal index for the assessment of the thermal environment. International Journal of Biometeorol, 43, 71-75. doi : Retrieved from https://doi.org/10.1007/s004840050118 
Höppe, P. (2002). Different aspects of assessing indoor and oudoor thermal comfort. energy and bulidings, 34. Retrieved from https://doi.org/10.1016/S03787788(02)00017-8

Irger, M. (2014). The Effect Of Urban Form On Urban Microclimate. (Doctor of Philosophy), New South Wales,

Jamei, E., Rajagopalan, P., Seyedmahmoudian, M., \& Jamei, Y. (2016). Review On The Impact Of Urban Geometry And Pedestrian Level Greening On Outdoor Thermal Comfort. Renewable and Sustainable Energy Reviews, 54, 10021017 doi : Retrieved from https://doi.org/10.1016/j.rser.2015.10.104

Jenks, M., \& Burgess, R. (2000). Compact Cities : Sustainable Urban Forms for Developing Countries : Routledge.

Jihad, A. S., \& Tahiri, M. (2016). Modeling the urban geometry influence on outdoor thermal comfort in the case of Moroccan microclimate. Urban Climate, 16, 25-42. doi: Retrieved from https://doi.org/10.1016/j.uclim.2016.02.002

Johansson, E. (2006). Influence of urban geometry on outdoor thermal comfort in à hot dry climate : A study in Fez, Morocco. Building and Environment, 41(10), 1326-1338.

Retrieved

from https://doi.org/10.1016/j.buildenv.2005.05.022

Katzschner, L., \& Thorsson, S. (2009). Microclimatic Investigations as Tool for Urban Design. Paper presented at the seventh International Conference on Urban Climate, Yokohama, Japan. www.researchgate.net

Kedissa, C., Outtas, S., \& Belarbi, R. (2016). The impact of height/width ratio on the microclimate and thermal comfort levels of urban courtyards. International Journal of Sustainable Building Technology and Urban Development, 7(3-4), 174-183. doi : Retrieved from https://doi.org/10.1080/2093761X.2017.1302830

Konarska, J., Lindberg, F., Larsson, A., Thorsson, S., \& Holmer, B. (2014). Transmissivity of solar radiation through crowns of single urban treesapplication for outdoor thermal comfort modelling. Theoretical and Applied Climatology, 117(3), 363-376. doi :10.1007/s00704-013-1000-3 Retrieved from https://doi.org/10.1007/s00704-013-1000-3

Kropf, K. S. (1993). An enquiry into the definition of built form in urban morphology. (unpublished PhD thesis), University of Birmingham, Birmingham.

Krüger, E. L., Minella, F. O., \& Rasia, F. (2011). Impact of urban geometry on outdoor thermal comfort and air quality from field measurements in Curitiba, Brazil. Building and Environment, 46(3), 621-634. doi: Retrieved from https://doi.org/10.1016/j.buildenv.2010.09.006

Kwon, C., Lee, K. J., \& Cho, S. (2019). Numerical Study of Balancing between Indoor Building Energy and Outdoor Thermal Comfort with a Flexible Building Element. Sustainability, 11, 6654. doi :10.3390/su11236654 Retrieved from https://doi.org/10.3390/su11236654

Lam, C. K. C., Cui, S., Liu, J., Kong, X., \& Hang, J. (2020). Effect of Acclimatization and Thermal History on Outdoor Thermal Comfort in Hot-Humid Area of China. In (pp. 877-886). Retrieved from https://doi.org/10.1007/978-981-139520-8_90

Lee, H., \& Mayer, H. (2018). Thermal comfort of pedestrians in an urban street canyon is affected by increasing albedo of building walls. International Journal of Biometeorology, 62. doi: Retrieved from https://doi.org/10.1007/s00484-018-1523-5

Lee, L. S. H., \& Jim, C. Y. (2019). Urban woodland on intensive green roof improved outdoor thermal comfort in subtropical summer. International Journal of 


$\begin{array}{lccccc}\text { Biometeorology, 63(7), 895-909. doi : } & \text { Retrieved from } \\ \text { https://doi.org/10.1007/s00484-019-01702-4 } & & & \end{array}$

Li, H. (2015). Pavement Materials for Heat Island Mitigation : Design and Management Strategies.

Lilly Rose, A., \& Devadas, M. D. (2009). Analysis of Land Surface Temperature and Land Use/Land Cover Types Using Remote Sensing Imagery - A Case In Chennai City, India. Paper presented at the The seventh International Conference on Urban Clim, Yokohama, Japan. www.citeseerx.ist.psu.edu

Lobaccaro, G., \& Acero, J. A. (2015). Comparative analysis of green actions to improve outdoor thermal comfort inside typical urban street canyons. Urban Climate, 14, 251-267. doi: Retrieved from https://doi.org/10.1016/j.uclim.2015.10.002

Lundgren-Kownacki, K., Hornyanszky, E. D., Chu, T. A., Olsson, J. A., \& Becker, P. (2018). Challenges of using air conditioning in an increasingly hot climate. International Journal of Biometeorology, 62(3), 401-412. doi: Retrieved from https://doi.org/10.1007/s00484-017-1493-z

Maller, A. (1998). Emerging urban form types in a city of the American Middle West. Journal of Urban Design, 3(2), 137-150. doi: Retrieved from https://doi.org/10.1080/13574809808724422

Masson, V. (2006). Urban surface modeling and the meso-scale impact of cities. Theoretical and Applied Climatology, 84(1), 35-45. doi : Retrieved from https://doi.org/10.1007/s00704-005-0142-3

Matallah, M., Djamel, A., Ahriz, A., \& Attia, S. (2020). Assessment of the Outdoor Thermal Comfort in Oases Settlements. Atmosphere, 11, 185. doi : Retrieved from https://doi.org/10.3390/atmos11020185

Matzarakis, A., Mayer, H., \& Iziomon, M. (1999). Applications of a universal thermal index : physiological equivalent temperature. International Journal of Biometeorology, 43(2), 76-84. doi: Retrieved from https://doi.org/10.1007/s004840050119

Matzarakis, A., Rutz, F., \& Mayer, H. (2007). Modelling radiation fluxes in simple and complex environments: basics of the RayMan model. International Journal of Biometeorology, 54(2), 131-139. doi : Retrieved from https://doi.org/10.1007/s00484-009-0261-0

Mi, J., Hong, B., Zhang, T., Huang, B., \& Niu, J. (2020). Outdoor thermal benchmarks and their application to climate-responsive designs of residential open spaces in a cold region of China. Building and Environment, 169, 106592. doi: Retrieved from https://doi.org/10.1016/j.buildenv.2019.106592

Mohajerani, A., Bakaric, J., \& Jeffrey-Bailey, T. (2017). The urban heat island effect, its causes, and mitigation, with reference to the thermal properties of asphalt concrete. Journal of Environmental Management, 197. doi: 5 Retrieved from https: //doi.org/10.1016/j.jenvman.2017.03.095

Morini, E., Touchaei, A., Castellani, B., Rossi, F., \& Cotana, F. (2016). The Impact of Albedo Increase to Mitigate the Urban Heat Island in Terni (Italy) Using the WRF Model. Sustainability, 8, 999. doi : Retrieved from https://doi.org/10.3390/su8100999

Moughtin, C. (2003). urban design: street and square: Architectural Press.

Muniz-Gäal, L. P., Pezzuto, C. C., Carvalho, M. F. H. d., \& Mota, L. T. M. (2020). Urban geometry and the microclimate of street canyons in tropical climate. Building and Environment, 169, 106547. doi: Retrieved from https://doi.org/10.1016/j.buildenv.2019.106547 
Ng, E. (2010). Designing High-Density Cities for Social and Environmental Sustainability. UK and USA : Earthscan. Retrieved from https://doi.org/10.4324/9781849774444

Nikolopoulou, M., \& Steemers, K. (2003). Thermal comfort and psychological adaptation as à guide for designing urban spaces. Energy and Buildings, 35(1), 95-101. doi : Retrieved from https://doi.org/10.1016/S03787788(02)00084-1

Nikolopoulou, M., Baker, N., \& Steemers, K. (1999). Thermal Comfort In Urban Spaces : Different Forms Of Adaptation. Paper presented at the International Conference : The Cities of Tomorrow, Barcelona.

Nuruzzaman, M. (2015). Urban Heat Island : Causes, Effects and Mitigation Measures -A Review. International Journal of Environmental Monitoring and Analysis, 3, 67-73. doi : Retrieved from https://doi.org/10.11648/j.ijema.20150302.15

Oke, T. R. (1987). Boundary Layer Climates. London : Methuen \& Co. Retrieved from https://doi.org/10.1007/BF00116120

Oke, T. R. (1988). Street Design and Urban Canopy Layer Climate. Energy and Buildings, 11(1-3). Retrieved from https://doi.org/10.1016/03787788(88)90026-6

Oke, T. R. (2004). Initial guidance to obtain representative meteorological observations at urban sites. Retrieved from Geneva, Switzerland: www.library.wmo.int

Oke, T., R. (1982). The energetic basis of the urban heat island. Quarterly journal of the meteorological society, 108(445), 1-24. doi : Retrieved from https://doi.org/10.1256/smsqj. 45501

Oke, T., R. (1988). Street design and urban canopy layer climate. Energy and Buildings, 11(1), 103-113. doi : Retrieved from https://doi.org/10.1016/0378-7788(88)90026-6

Oke. (2006). Initial guidance to obtain representative meteorological observations at urban sites. Retrieved from

Oliveira, V. (2016). Urban Morphology An Introduction to the Study of the Physical Form of Cities. Switzerland : Springer International Publishing

Oliver, J. E. (2005). Encyclopedia Of World Climatology Springer Netherlands. Retrieved from https://doi.org/10.1007/1-4020-3266-8

Orosa, J., Costa, Á., Rodríguez-Fernández, A., \& Roshan, G. (2014). Effect of climate change on outdoor thermal comfort in humid climates. Journal of environmental health science \& engineering, 12, 46. doi: Retrieved from https://doi.org/10.1186/2052-336X-12-46

Ouali, K., El Harrouni, K., Abidi, M. L., \& Diab, Y. (2020). Analysis of Open Urban Design as a tool for pedestrian thermal comfort enhancement in Moroccan climate. Journal of Building Engineering, 28, 101042. doi: Retrieved from https://doi.org/10.1016/j.jobe.2019.101042

Perini, K., Chokhachian, A., Dong, S., \& Auer, T. (2017). Modeling and simulating urban outdoor comfort: Coupling ENVI-Met and TRNSYS by grasshopper. Energy and Buildings, 152(Supplement C), 373-384. doi: Retrieved from https://doi.org/10.1016/j.enbuild.2017.07.061

Pirard, P., Vandentorren, S., Pascal, M., Laaidi, K., Le Tertre, A., Cassadou, S., \& Ledrans, M. (2005). Summary of the mortality impact assessment of the 2003 heat wave in France. Euro Surveill, 10(7), 153-156. Retrieved from https://doi.org/10.2807/esm.10.07.00554-en 
Pramanik, S., \& Punia, M. (2019). Land use/land cover change and surface urban heat island intensity : source-sink landscape-based study in Delhi, India. Environment, Development and Sustainability. doi: Retrieved from https://doi.org/10.1007/s10668-019-00515-0

Prasad, N., Ranghieri, F., Shah, F., \& Trohanis, Z. (2009). Climate Resilient Cities : A Primer on Reducing Vulnerabilities to Disasters. Washington, DC : World Bank. Retrieved from https://doi.org/10.1596/978-0-8213-7766-6

Priyadarsini, R., Hien, W. N., \& Wai David, C. K. (2008). Microclimatic modeling of the urban thermal environment of Singapore to mitigate urban heat island. Solar Energy, 82(8), 727-745. doi: Retrieved from https://doi.org/10.1016/j.solener.2008.02.008

Qaid, A., Bin Lamit, H., Ossen, D. R., \& Raja Shahminan, R. N. (2016). Urban heat island and thermal comfort conditions at micro-climate scale in a tropical planned city. Energy and Buildings, 133, 577-595. doi: 10.1016/j.enbuild.2016.10.006 Retrieved from https://doi.org/10.1016/j.enbuild.2016.10.006

Rahman, M. A., Moser, A., Rötzer, T., \& Pauleit, S. (2017). Within canopy temperature differences and cooling ability of Tilia cordata trees grown in urban conditions. Building and Environment, 114, 118-128. doi:

https://doi.org/10.1016/j.buildenv.2016.12.013

Raj, S., Paul, S. K., Chakraborty, A., \& Kuttippurath, J. (2020). Anthropogenic forcing exacerbating the urban heat islands in India. J Environ Manage, 257, 110006. doi: Retrieved from https://doi.org/10.1016/j.jenvman.2019.110006

Rajagopalan, P., Lim, K. C., \& Jamei, E. (2014). Urban heat island and wind flow characteristics of a tropical city. Solar Energy, 107(Supplement C), 159-170. doi: Retrieved from https://doi.org/10.1016/j.solener.2014.05.042

Roa-Espinosa, A., Wilson, T., Norman, J., \& Johnson, K. (2003). Predicting the impact of urban development on stream temperature using a thermal urban runoff model (TURM). Proc., U.S. EPA National Conf. On Urban Stormwater: Enhancing Programs at the Local Level, 369-389.

Roaf, S., Crichton, D., \& Nicol, F. (2009). Adapting Buildings and Cities for Climate Change : A 21st Century Survival Guide. Oxford, United Kingdom: Taylor \& Francis Ltd. Retrieved from https://doi.org/10.4324/9780080961279

Rodríguez Algeciras, J. A., Consuegra, L. G. a., \& Matzarakis, A. (2016). Spatialtemporal study on the effects of urban street configurations on human thermal comfort in the world heritage city of Camagüey-Cuba. Building and Environment, 101, 85-101. doi: Retrieved from https://doi.org/10.1016/j.buildenv.2016.02.026

Rose, L., Horrison, E., \& Venkatachalam, L. J. (2011). Influence Of Built Form On The Thermal Comfort Of Outdoor Urban Spaces. Paper presented at the The 5th International Conference of the International Forum on Urbanism (IFoU), Singapore.

Rosenfeld, A. H., Akbari, H., Romm, J. J., \& Pomerantz, M. (1998). Cool communities: strategies for heat island mitigation and smog reduction. Energy and Buildings, 28(1), 51-62. Retrieved from https://doi.org/10.1016/S03787788(97)00063-7

Roshan, G., Saleh Almomenin, H., da Silveira Hirashima, S. Q., \& Attia, S. (2019). Estimate of outdoor thermal comfort zones for different climatic regions of Iran. Urban Climate, 27, 8-23. doi: Retrieved from https://doi.org/10.1016/j.uclim.2018.10.005 
Roth, M., \& Chow, W. T. (2012). A historical review and assessment of urban heat island research in Singapore. Singapore Journal of Tropical Geography, 33, 381-397. doi : Retrieved from https://doi.org/10.1111/sjtg.12003

Rui, L., Buccolieri, R., Gao, Z., Gatto, E., \& Ding, W. (2019). Study of the effect of green quantity and structure on thermal comfort and air quality in an urban-like residential district by ENVI-met modelling. Building Simulation, 12(2), 183194. doi : Retrieved from https://doi.org/10.1007/s12273-018-0498-9

Sailor, D. (2006). Mitigation of urban heat islands-Recent progress and futurs prospects. Paper presented at the Paper presented at the Paper presented on american meteorological society 6th symposium on the urban environment and forum on managing our physical and natural resources. http://www.cecs.pdx.edu/ sailor

Santamouris, M. (2014). On the energy impact of urban heat island and global warming on buildings. Energy and Buildings, 82, 100-113. doi: Retrieved from https://doi.org/10.1016/j.enbuild.2014.07.022

Santamouris, M., adnot, J., Klitsikas, N., Orphelin, M., Lopes, C., \& Sanchez, F. (2004). Cooling the cities : Energy Efficent Cooling systems and techniques for urban buildings. Greece : university of Paris.

Saud Alznafer, B. M. (2014). The impact of neighbourhood geometries on outdoor thermal comfort and energy consumption from urban dwellings a case study of the riyadh city, the kingdom of saudi arabia. (Doctor Of Philosophy), Cardiff University,

Shahmohamadi, P., Che-Ani, A. I., Tawil, N. M., Maulud, K. N. A., \& Tahir, M. M. (2011). The Conceptual Framework to Achieve Energy Consumption Balance in Kuala Lumpur Shophouses for Mitigating Urban Heat Island Effects with Focusing On Anthropogenic Heat Factor. 2(1). doi: Retrieved from https://doi.org/10.22452/jscp.vol2no1.3

Shashua-Bar, L., Pearlmutter, D., \& Erell, E. (2011). The influence of trees and grass on outdoor thermal comfort in à hot-arid environment. International Journal of Climatology, 31(10), 1498-1506. doi: Retrieved from https://doi.org/10.1002/joc.2177

Shashua-Bar, L., Pearlmutter, D., \& Erell, E. (2019). Microscale Vegetation Effects On Outdoor Thermal Comfort In A Hot-Arid Environment. 1-4.

Spagnolo, J., \& de Dear, R. (2003). A field study of thermal comfort in outdoor and semi-outdoor environments in subtropical Sydney Australia. Building and Environment, 38(5), 721-738. doi : Retrieved from https://doi.org/10.1016/S0360-1323(02)00209-3

Srivanit, M., \& Jareemit, D. (2020). Modeling the influences of layouts of residential townhouses and tree-planting patterns on outdoor thermal comfort in Bangkok suburb. Journal of Building Engineering, 101262. doi: Retrieved from https://doi.org/10.1016/j.jobe.2020.101262

Taha, H., Akbari, H., Rosenfeld, A., \& Huang, J. (1988). Residential cooling loads and the urban heat island-the effects of albedo. Building and Environment, 23(4), 271-283. doi : Retrieved from https://doi.org/10.1016/03601323(88)90033-9

Thorsson, S., Lindberg, F., Björklund, J., Holmer, B., \& Rayner, D. (2011). Potential changes in outdoor thermal comfort conditions in Gothenburg, Sweden due to climate change : the influence of urban geometry. International Journal of Climatology, 31(2), 324-335. doi : Retrieved from https://doi.org/10.1002/joc.2231 
Tong, S., Wong, N. H., Tan, C. L., Jusuf, S. K., Ignatius, M., \& Tan, E. (2017). Impact of urban morphology on microclimate and thermal comfort in northern China. Solar Energy, 155(Supplement C), 212-223. doi: Retrieved from https://doi.org/10.1016/j.solener.2017.06.027

Tsai, Y.-H. (2005). Quantifying Urban Form: Compactness versus 'Sprawl'. Urban Studies, 42(1), 141-161. doi : Retrieved from https://doi.org/10.1080/0042098042000309748

Ünlü, T. (2011). Towards the Conceptualization of Piecemeal Urban Transformation : The Case of Mersin, Turkey. Built Environment, 37(4), 445-461. doi : Retrieved from https://doi.org/10.2148/benv.37.4.445.

Vasilikou, C., \& Nikolopoulou, M. (2019). Outdoor thermal comfort for pedestrians in movement : thermal walks in complex urban morphology. International Journal of Biometeorology (Special Issue:Subjective approaches to thermal perception), 1-15. doi: Retrieved from https://doi.org/10.1007/s00484019-01782-2

Voogt, J. A., \& Oke, T. R. (2003). Thermal remote sensing of urban climates. Remote Sensing of Environment, 86(3), 370-384. doi: Retrieved from https://doi.org/10.1016/S0034-4257(03)00079-8

Wai, K.-M., Yuan, C., Lai, A., \& Yu, P. K. N. (2020). Relationship between pedestrianlevel outdoor thermal comfort and building morphology in à high-density city. Science of The Total Environment, 708, 134516. doi: Retrieved from https://doi.org/10.1016/j.scitotenv.2019.134516

Wang, Y., \& Akbari, H. (2016). The effects of street tree planting on Urban Heat Island mitigation in Montreal. Sustainable Cities and Society, 27(Supplement C), 122-128. doi: Retrieved from https://doi.org/10.1016/j.scs.2016.04.013

Willemsen, E., \& Wisse, J. A. (2007). Design for wind comfort in The Netherlands: Procedures, criteria and open research issues. Journal of Wind Engineering and Industrial Aerodynamics, 95(9), 1541-1550. doi: Retrieved from https://doi.org/10.1016/j.jweia.2007.02.006

Xu, M., Hong, B., Mi, J., \& Yan, S. (2018). Outdoor thermal comfort in an urban park during winter in cold regions of China. Sustainable Cities and Society, 43, 208-220. doi: Retrieved from https://doi.org/10.1016/j.scs.2018.08.034

Xuan, Y., Yang, G., Li, Q., \& Mochida, A. (2016). Outdoor thermal environment for different urban forms under summer conditions. Building Simulation, 9(3), 281-296. doi: Retrieved from https://doi.org/10.1007/s12273-016-0274-7

Yahia, M. W., Johansson, E., Thorsson, S., Lindberg, F., \& Rasmussen, M. I. (2017). Effect of urban design on microclimate and thermal comfort outdoors in warm-humid Dar es Salaam, Tanzania. International Journal of Biometeorology, 62, 373-385. doi :10.1007/s00484-017-1380-7 Retrieved from https://doi.org/10.1007/s00484-017-1380-7

Yang, L., Qian, F., Song, D.-X., \& Zheng, K.-J. (2016). Research on Urban Heat-Island Effect. Procedia Engineering, 169(Supplement C), 11-18. doi: Retrieved from https://doi.org/10.1016/j.proeng.2016.10.002

Yang, W., Wong, N. H., \& Lin, Y. (2015). Thermal Comfort in High-rise Urban Environments in Singapore. Procedia Engineering, 121(Supplement C), 2125-2131. doi: Retrieved from https://doi.org/10.1016/j.proeng.2015.09.083

Yasa, E. (2016). Computational evaluation of building physics-The effect of building form and settled area, microclimate on pedestrian level comfort around buildings. Building Simulation, 9(4), 489-499. Retrieved from https://doi.org/10.1007/s12273-016-0277-4 
Yilmaz, S., Akif Irmak, M., \& Matzarakis, A. (2013). The importance of thermal comfort in different elevation for city planning. Global nest journal, 15(3), 408-420. doi : Retrieved from https://doi.org/10.30955/gnj.001053

Yow, D. M. (2007). Urban Heat Islands : Observations, Impacts, and Adaptation. Geography Compass, 1, 1227-1251. doi : Retrieved from https://doi.org/10.1111/j.1749-8198.2007.00063.x

Zaker Haghighi, K., Majedi, H., \& Habib, F. (2010). The Effective Indexes On Urban Fabric Typology. Hoviat shahr, 4(7), 105-112.

Zhang, Y., Du, X., \& Shi, Y. (2017). Effects of street canyon design on pedestrian thermal comfort in the hot-humid area of China. International Journal of Biometeorology, 61(8), 1421-1432. doi : Retrieved from https://doi.org/10.1007/s00484-017-1320-6

Zhen, M., Dong, Q., Chen, P., Ding, W., Zhou, D., \& Feng, W. (2020). Urban outdoor thermal comfort in western China. Journal of Asian Architecture and Building Engineering, 1-29. doi: Retrieved from https://doi.org/10.1080/13467581.2020.1782210

Zhong, Chen, G., Chengguo, L., Gao, S., \& Li, L. (2019). A Specific Study on the Impacts of PM2.5 on Urban Heat Islands with Detailed In Situ Data and Satellite Images. Sustainability, 11, 7075. doi : Retrieved from https://doi.org/10.3390/su11247075

Zhou, B., Rybski, D., \& Kropp, J. P. (2017). The role of city size and urban form in the surface urban heat island. Scientific Reports, 7(1), 4791. doi :10.1038/s41598-017-04242-2 Retrieved from https://doi.org/10.1038/s41598-017-04242-2

Zhou, W., Cao, F., \& Wang, G. (2019). Effects of Spatial Pattern of Forest Vegetation on Urban Cooling in a Compact Megacity. Forests, 10(3), 1-15. doi : Retrieved from https: //doi.org/10.3390/f10030282

Zhu, Z., Liang, J., Sun, C., \& Han, Y. (2020). Summer Outdoor Thermal Comfort in Urban Commercial Pedestrian Streets in Severe Cold Regions of China. Sustainability, 12, 1-20. doi : Retrieved from https://doi.org/10.3390/su12051876

[NRTEE], N. R. T. o. t. E. a.t. E. (2003). Environmental Quality in Canada Cities : the Federal Role. Retrieved from Ottawa : 